\title{
MOTIVASI ENTREPRENEURSHIP DALAM MENINGKATAN LIFESKILL PESERTA DIDIK DI SD NU INSAN CENDEKIA KEDIRI
}

\author{
Ainul Naim dan Siti Mahmudah \\ Institut Agama Islam Negeri (IAIN) Kediri \\ ainun0872@gmail.com
}

\begin{abstract}
This study aims to determine the role of motivation given by educators in terms of entrepreneurship which will then increase the lifeskills in learners on SDNU Insan Cendekia Ngadiluwih Kediri.This research uses qualitative research method. Research strategy using phenomenological approach. This approach is perceived to understand the meaning of human events and interactions in their particular situations. Researchers take focus in grade 3 and 4 as many as 4 classes. And data collection techniques that researchers take ie from the method of interviewing and documentation. The result of the research concludes that, (1) Prophet Muhammad has a strategy in doing entrepreneurship activities in the form of honesty, maintaining trust, confidence, spirit, business that is really clean, ethical, prospect, diligent, persistent, independent, never give up, take a risk, and have egalitarian personality, (2) On applying entrepreneurship in SDNU Insan Cendekia done by learners and parents, can not be separated from educators who provide an entrepreneurship motivation. From the application of entrepreneurship, it will increase the lifeskills contained in the learner that includes personal skills and social life skills, and (3) Along with held entrepreneurship in
\end{abstract}


learners. Apparently there are several advantages and disadvantages of the application of entrepreneurship. This is because this activity is still done first in this school. Then the need for an evaluation so that the future can be improved again.

Key words: Motivation entrepreneurship, and Lifeskills

\begin{abstract}
Abstrak
Penelitian ini bertujuan untuk mengetahui peran dari motivasi yang diberikan pendidik dalam hal kewirausahaan yang kemudian akan meningkatkan kecakapan bidup dalam peserta didik pada SDNU Insan Cendekia Ngadiluwih Kediri. Penelitian ini menggunakan metode penelitian kualitatif. Strategi penelitian dengan menggunakan pendekatan fenomenologis. Pendekatan ini dirasa dapat memahami makna dari berbagai peristiwa dan interaksi manusia didalam situasinya yang khusus. Peneliti mengambil fokus penelitian pada kelas 3 dan 4 sebanyak 4 kelas. Teknik pengumpulan data yakni metode wawancara dan dokumentasi. Hasil penelitian menunjukkan (1) Nabi Mubammad memiliki strategi dalam melakukan kegiatan kewirausahaan berupa kejujuran, amanah, percaya diri, spirit, bisnis yang benar-benar bersih, beretiket, berprospek cerah, rajin, tekun, mandiri, pantang menyerah, berani mengambil resiko, dan memiliki pribadi yang egaliter, (2) Pada penerapan kewirausabaan di SD NU Insan Cendekia yang dilakukan oleh peserta didik maupun orangtua, tidak lepas dari pendidik yang memberikan suatu motivasi kewirausahaan. Dari penerapan kewirausahaan, maka akan meningkatkan kecakapan bidup yang terdapat dalam peserta didik yang meliputi kecakapan personal dan kecakapan bidup sosial, dan (3) Seiring dengan diadakanya kewirausahaan pada peserta didik. Ternyata terdapat beberapa kelebihan dan kekurangan atas penerapan kewirausahaan tersebut dikarenakan kegiatan ini baru dilakukan pertama kali di sekolah ini. Maka perlu adanya suatu evaluasi agar kedepannya dapat ditingkatkean lagi.
\end{abstract}

Kata Kunci: Motivasi kewirausahaan, dan Kecakapan Hidup

\title{
A. Pendahuluan
}

Menurut Ki Hajar Dewantara di dalam bukunya Wiji Suwarno, menyebutkan bahwa pendidikan adalah tuntutan bagi 
pertumbuhan anak-anak. Artinya pendidikan menuntut segala kekuatan kodrat yang ada pada diri anak-anak, agar mereka sebagai manusia sekaligus sebagai anggota masyarakat dapat mencapai keselamatan dan kebahagiaan setinggi-tingginya. ${ }^{1}$ Dalam proses pendidikan terutama di sekolah, pastinya tidak terlepas dari peran serta pendidik dan peserta didik. Pendidik memiliki tuntutan untuk mendidik para peserta didiknya. Para pendidik didorong untuk selalu terus mengembangkan kreativitasannya untuk dapat meningkatkan lifeskills para peserta didik. Sebisa mungkin seorang pendidik dalam proses pembelajaran untuk memberikan motivasimotivasi terhadap peserta didiknya.

Motivasi mengutip pendapatnya Rizka Iftikhah merupakan suatu pengertian yang melingkupi semua penggerak alasan, atau dorongan dalam diri manuasia yang memyebabkan ia berbuat sesuatu. $^{2}$ Motivasi adalah suatu usaha yang disadari untuk menggerakkan, menggarahkan dan menjaga tingkah laku seseorang agar ia terdorong untuk bertindak melakukan sesuatu sehingga mencapai hasil atau tujuan tertentu. ${ }^{3}$ Motivasi menurut Abraham Maslow yang dikutip oleh Purwa Atmaja Prawira, mendefinisikan motivasi adalah sesuatu yang bersifat konstan (tetap), tidak pernah berakhir, berfluktuasi dan bersifat kompleks, dan hal itu kebanyakan merupakan karakteristik universal pada setiap kegiatan organisme. ${ }^{4}$ Maslow membedakan kebutuhan manusia menjadi dua kelompok, yaitu kebutuhan metabolism dan kebutuhan untuk tumbuh. ${ }^{5}$

Motivasi-motivasi itu penting untuk menumbuhkan Life skills peserta didik. Life skills sendiri dengan mengutip pendapatnya Slamet PH didefinisikan sebagai kemampuan, kesanggupan dan keterampilan yang diperlukan oleh seseorang untuk menjalankan

1 Wiji Suwarno, Dasar-dasar Ilmu Pendidikan (Sleman : Ar-ruzz Media Group, 2009), hlm. 21.

2 Rizka Iftikhah, "Pengaruh Perhatian Orang Tua Terhadap Motivasi Belajar Siswa“", Jurnal Ilmiah Pendidikan Bimbingan dan Konseling, Jurnal online. Diakses pada tanggal 16 November 2016.

3 Ghullam Hamdu, “ Pengaruh Motivasi Belajar Siswa., hlm. 81.

4 Purwa Atmaja Prawira, Psikologi Pendidikan dalam Perspektif Baru (Yogyakarta: Ar-Ruzz Media, 2014), hlm. 332.

${ }^{5}$ Ibid., hlm. 319-320. 
kehidupan dengan nikmat dan bahagia. ${ }^{6}$ Secara sederhana life skills bisa disebut sebagai kecakapan yang dibutuhkan untuk bekerja selain kecakapan dalam bidang akademik. Lifeskills ini merupakan suatu indikator dari salah satu suksesnya lembaga pendidikan formal ( sekolah ). Dengan adanya lifeskills dapat membekali suatu generasi muda untuk mempersiapkan masa depannya. Sehingga dengan adanya dinamika globalisasi saat ini, peserta didik membutuhkan penguasaan ketrampilan yang profesional dan yang berkaitan dengan teknologi yang canggih bukan hanya dengan kekuatan otot saja.

Motivasi itu juga yang menjadi suatu sumber tenaga dalam mengerjakan suatu hal agar bisa mencapai suatu tujuan yang diinginkan. Oleh karena itu, pendidik sangat perlu menumbuhkan motivasi untuk peserta didik, agar dari peserta didik tersebut dapat mencapai cita-cita yang telah diinginkannya. Tidak hanya pada bidang pelajaran saja pendidik mengajarkan ilmu terhadap peserta didiknya. Terlebih dari itu, pendidik juga harus mengajarkan ilmu yang berkaitan dengan entrepreneurship terhadap peserta didiknya.

Entrepreneurship merupakan satu istilah yang sering kali masyarakat sebutkan. Entrepreneurship bisa juga dikatakan sebagai suatu kegiatan kewirausahaan. Wirausaha adalah seorang pembuat keputusan yang membantu terbentuknya sistem ekonomi perusahaan yang bebas. Sebagian besar pendorong perubahan, inovasi dan kemajuan di perekonomian kita akan datang dari para wirausaha; orang yang memiliki kemampuan untuk mengambil resiko dan mempercepat pertumbuhan ekonomi. Menurut Drucker dalam jurnalnya Aprijon, kewirausahaan suatu kemampuan untuk menciptakan sesuatu yang baru dan berbeda (Ability to create the new and different thing). ${ }^{7}$ Jadi, secara umum kewirausahaan (entrepreneurship) adalah kemampuan kreatif dan inovatif yang

${ }^{6}$ Slamet PH, Pendidikan Kecakapan Hidup di Sekolah Lanjutan Tingkat Pertama: Konsep dan Pelaksanaan (Jakarta: Direktorat Sekolah Lanjutan Tingkat Pertama, 2002), hlm. 154.

Aprijon, " Kewirausahaan dan Pandangan Islam ", Menara, Volume.12, Nomor.01, (Januari-Juni 2013), hlm. 3. 
dijadikan kiat, dasar, sumber daya, proses, dan perjuangan untuk menciptakan nilai tambah barang dan jasa yang dilakukan dengan keberanian untuk menghadapi resiko. ${ }^{8}$ Seorang entrepreneur akan memiliki karakter yang melekat pada dirinya, seperti : percaya diri, berorientasi tugas dan hasil, pengambilan resiko, kepemimpinan, keorisinilan, berorientasi ke masa depan, serta jujur dan tekun. ${ }^{9}$

Di dalam buku sejarah lengkap Rasulullah menyatakan bahwa Nabi Muhammad SAW merupakan sosok wirausaha. Kewirausahaan yang telah dilakukan Nabi Muhammad tak lain sebagai pedagang, pengembala kambing, dan lain sebagainya. Profesi ini dilakukan oleh Nabi Muhammad SAW dengan sungguhsungguh, hingga akhirnya Nabi Muhammad menjadi sosok wirausaha yang sukses. Sehingga timbul suatu pandangan bahwa Nabi Muhammad SAW menjadi suri tauladan dalam berwirausaha. Akan tetapi, lambat laun konsep dari entrepreneurship ini cenderung dengan profesi sebagai seorang pedagang. Padahal jika dikaji lagi, konsep dari entrepreneurship ini menunjukkan pada konsep yang sangat luas.

Nabi Muhammad saw adalah pedagang sejati, dan beliau masa mudanya berjulukan al-Amin karena memiliki kredibilitas tinggi. Saat usia 12 tahun Muhammad, ketika pertama kali mendapat pengalaman istimewa dalam berpetualang. Sejak itulah Muhammad melakukan semacam magang (internship) yang berguna kelak ketika beliau mengelola bisnis sendiri. Saat itu dia mengikuti pamannya pergi berdagang ke Syiria. Pengalaman-pengalaman yang dialaminya menjadikan Muhammad sebagai pribadi yang mandiri, pantang menyerah, kuat yang selalu siap mengambil keputusan pada saat-saat sulit. ${ }^{10}$

\footnotetext{
2016), hlm. 38 .

9 Novan Ardy Wiyani, Teacherpreneurship ( Jogjakarta : Ar-Ruzz Media, 2012 ), hlm. 46.

10 Novi Indriyani Sitepu, "Prilaku Bisnis Muhammad SAW Sebagai Entrepreneur Dalam Filsafat Ekonomi Islam “, Human Falah, Volume 3. No. 1, (Januari - Juni 2016), hlm. 22.
}

${ }^{8}$ Agus Siswanto, The Power Of Islamic Entrepreneurship, (Jakarta: Amzah, 
Saat pamannya bangkrut, Muhammad tidak lantas larut dalam kepedihan. Sebaliknya, dengan sigap ia segera mengambil keputusan. Mencari alternatif atas kebangkrutan sang paman hingga ia menemukan solusi untuk melakukan perdagangan keliling sendiri. Berbekal pengalaman dan keterampilannya dalam berdagang, Muhammad mulai menawarkan jasa menjualkan barang dagangan para saudagar kaya Mekkah. Muhammad sudah mahir berdagang dengan model seperti ini, karena sejak kecil ia sudah terbiasa menjual barang dagangan di sekitar Ka'bah pada musim haji. Pengalaman-pengalaman inilah yang membuat modal dasar bagi perkembangan jiwa entrepreneurship Muhammad. Muhammad adalah pelaku bisnis (pedagang), dimana usianya 20an perdagangan beliau sudah menembus negara-negara tetangga, bahkan dia lebih lama menjadi pedagang ketimbang nabi.

Selain skill berdagang yang beliau miliki. Muhammad juga memiliki keterampilan membangun hubungan (jaringan) dengan kepala suku-suku Kabilah Arab selaku kawan-kawan kakeknya. Muhammad mengajukan berbagai penawaran kepada saudagar kaya Makkah (syirkah dan mudharabah). ${ }^{11}$ Sejarah mencatat salah seorang di antara pemilik modal tersebut adalah seorang janda kaya bernama Siti Khadijah yang menawarkan satu kemitraan berdasarkan pada sistem bagi hasil (profit sharing). Dengan demikian, terbukalah kesempatan bagi Muhammad untuk memasuki dunia bisnis dengan cara menjalankan modal orang lain, baik dengan upah (fee based) maupun dengan profit sharing.

Muhammad adalah tokoh yang paling ideal untuk dijadikan teladan. Bermodalkan kemandirian yang Muhammad miliki sejak kecil, beliau telah berhasil mengelola barang dagangan yang diamanahkan Khadijah kepada Muhammad selaku pemegang amanah. Kecakapannya sebagai seorang entrepreneur telah mendatangkan keuntungan yang melimpah. Ketika keahlian telah dikuasianya, ia menawarkan diri menjadi manajer perdagangan para investor. Kecakapannya sebagai wirausahawan telah mendatangkan

\footnotetext{
${ }^{11}$ Ibid., hlm. 23.
} 
keuntungan besar baginya dan investornya. Tidak satupun jenis bisnis yang ia tangani mendapat kerugian. Sehingga membuat Siti Khadijah terkesan padanya. Muhammad sebelum menikah, menjadi manajer perdagangan Khadijah ke pusat perdagangan Habasyah di Yaman. Muhammad juga empat kali memimpin ekspedisi perdagangan untuk Khadijah ke Syiria dan Jorash di Yordania. Serta beliau juga pernah ke Bahrain, sebelah Timur Semenanjung Arab. Dengan demikian di usia muda Muhammad sudah menjadi pedagang regional, karena daerah perdagangannya meliputi hampir seluruh Jazirah Arab. ${ }^{12}$

Seiring dengan berkembangnya waktu, Pada 31 Desember 2015 di Indonesia telah digemparkan dengan adanya istilah MEA ( Masyarakat Ekonomi Asean ). ${ }^{13}$ Semua masyarakat ASEAN sangat antusias terhadap adanya MEA ini. MEA diharapkan dapat menjunjung perekonomian masyarakat ASEAN yang bergabung didalamnya. Dengan adanya MEA ini, menjadikan masyarakat ASEAN melakukan penawaran produknya menjadi lebih luas tidak hanya pada lingkup antar desa saja akan tetapi bisa merambah luas dengan lingkup antar negara. Ternyata dengan diadakannya MEA ini memberikan manfaat tersendiri pada bidang pendidikan.

Dengan menanamkan semangat entrepreneurship di Sekolah Dasar, besar harapan pendidik untuk mampu membentuk lifeskills mereka sedini mungkin. Tidak hanya itu saja, peserta didik dapat juga akan termotivasi untuk meniru metode berdagangnya Nabi Muhammad SAW yang kemudian hari dapat diterapkan dengan sebaik-baiknya. Pada dasarnya segala yang dilakukan oleh Nabi Muhammad SAW merupakan Sunnah, yang kemudian akan mendatangkan pahala bagi orang yang menjalankannya.

${ }^{12}$ Ibid., hlm. 24-25.

${ }^{13}$ Boy Syamsul Bakhri, "Masyarakat Ekonomi Asean (MEA) dan Tinjauan dari Perspektif Ekonomi Syariah", Jurnal Ekonomi, Vol. 25, No. 2, (Desember 2015), hlm. 63. 


\section{B. Pembahasan}

\section{Motivasi Entrepreneurship}

Di dalam Al-Qur'an dan Hadist terdapat hal-hal yang menjelaskan tentang entrepreneurship dan dirasa dapat memotivasi umat Islam untuk melakukan entrepreneurship. Selanjutnya ayat AlQur'an dan Hadist-nya dijelaskan sebagai berikut:

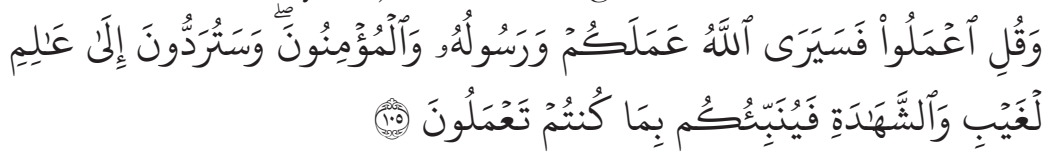

Artinya: "Dan Katakanlah: Bekerjalah kamu, Maka Allab dan Rasul-Nya serta orang-orang mukmin akan melihat pekerjaanmu itu, dan kamu akan dikembalikan kepada (Allah) yang mengetahui akan yang ghaib dan yang nyata, lalu diberitakanNya kepada kamu apa yang telah kamu kerjakan. "14

Ayat ini menunjukkan bahwa Allah SW'T memerintahkan kepada seluruh umat Islam untuk bekerja karena pekerjaan tersebut akan dinilai oleh Allah, Rasul-Nya, serta orang-orang yang beriman. Penilaian pekerjaan tersebut akan menentukan posisi kita di mata Allah dan Rasul-Nya. Oleh sebab itu, setiap muslim haruslah bekerja sesuai dengan nilai-nilai Islam. ${ }^{15}$

Perintah untuk bekerja dan berwirausaha disebutkan dalam ayat lainnya yaitu :

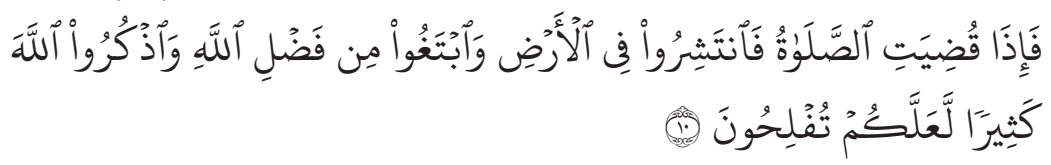

Artinya: "Apabila telah ditunaikan shalat, Maka bertebaranlah kamu di muka bumi; dan carilah karunia Allah dan ingatlah Allah banyak-banyak supaya kamu beruntung. "\$6

Berdasarkan kedua ayat ini, umat Islam diperintahkan untuk berusaha dengan bekerja dan berwirausaha agar mendapatkan rezeki dari Allah SWT sebagai sebuah sumber penghasilan. Perintah tersebut bukanlah hal yang biasa karena disandingkan dengan kewajiban untuk melaksanakan shalat Jumat yang merupakan

\footnotetext{
${ }^{14}$ QS. Al-Taubah: 105

15 Agus Siswanto, The Power Of Islamic., hlm. 11.

${ }^{16}$ QS. Al-Jumu'ah: 10.
} 
kewajiban bagi setiap muslim. Oleh karena itu, bisa disimpulkan pula bahwa berwirausaha merupakan kewajiban bagi setiap muslim untuk mendapatkan penghasilan yang halal.

Selanjutnya juga terdapat hadist yang menjelaskan tentang motivasi ber-entrepreneurship, sebagai berikut: sebuah riwayat yang mursal menyebutkan,

$$
\text { عليكم بالتّجا رة فِانّ فيها تسعة اً عشا ر الرّزق ق }
$$

Artinya: "Hendaklah kamu berdagang karena di dalamnya terdapat sembilan pulub persen pintu rezeki. "( HR.Ahmad )

Sedangkan dalam riwayat yang lainnya menjelaskan,

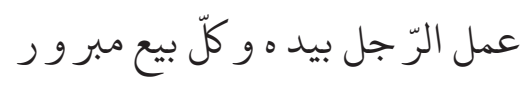

Artinya: "Pekerjaan seseorang dengan tangannya dan setiap transaksi jual beli yang mabrur (dibenarkan ). "( HR.Ahmad dan Al-Bazzar)

Dua hadis tersebut cukup menjadi pedoman bagi umat Islam untuk melakukan aktivitas kewirausahaan sebagai sumber penghasilannya. Hadis ini bukan muncul tanpa ada sebabnya. Asbab al-wurud dari hadis ini adalah kebiasaan masyarakat Quraisy yang telah terbiasa berdagang sehingga Nabi memberikan motivasi agar mereka lebih bersemangat lagi dalam berdagang. Saat ini, riwayat ini menjadi motivasi bagi umat Islam untuk bekerja dan berwirausaha sebagai sarana untuk memenuhi kebutuhan hidup. ${ }^{17}$

\section{Life skills ( Kecakapan Hidup )}

Life skills dapat dinyatakan sebagai kecakapan untuk hidup. Program pendidikan life skills adalah pendidikan yang dapat memberikan bekal ketrampilan yang praktis, terpakai, terkait dengan kebutuhan pasar kerja, peluang usaha dan potensi ekonomi atau industri yang ada di masyarakat. Life skills ini memiliki cakupan yang luas, berinteraksi antara pengetahuan yang diyakini sebagai unsur penting untuk hidup lebih mandiri. Life skills mengacu pada berbagai ragam kemampuan yang diperlukan seseorang untuk menempuh kehidupan dengan

\footnotetext{
17 Ibid., hlm. 12.
} 
sukses, bahagia dan secara bermartabat di masyarakat. Life skills merupakan kemampuan komunikasi secara efektif, kemampuan mengembangkan kerja sama, memeiliki kesiapan serta kecakapan untuk bekerja, dan memiliki karakter dan etika untuk terjun ke dunia kerja. ${ }^{18}$ Sedangkan menurut Slamet PH dalam bukunya Jamal Ma'mur Asmani mendefinisikan life skills sebagai kemampuan, kesanggupan, ketrampilan yang diperlukan oleh seseorang untuk menjalankan kehidupan dengan nikmat dan bahagia. Kecakapan tersebut mencakup segala aspek sikap dan perilaku manusia sebagai bekal untuk menjalankan kehidupannya. ${ }^{19}$

Secara umum kecakapan hidup dibedakan menjadi kecakapan umum (general life skills) dan kecakapan khusus (specific life skills). Kecakapan hidup umum adalah kecakapan-kecakapan hidup yang dibutuhkan seseorang untuk dapat hidup dan berada di tengah-tengah masyarakat. Kecakapan hidup umum general life skills) dibagi menjadi: (a) kecakapan personal yang terdiri dari: kesadaran diri dan kecakapan berpikir, (b) Kecakapan hidup sosial yang terdiri dari kecakapan komunikasi dan kecakapan kerjasama. ${ }^{20}$ Sedangkan kecakapan hidup khusus (specific life skills) diperlukan seseorang untuk menghadapi problema bidang tertentu. Life skills yang bersifat khusus biasanya disebut juga sebagai kompotensi teknis (technical competencies) yang terkait dengan materi mata pelajaran atau mata diklat tertentu dan pendekatan pembelajarannya. Specific life skills mencakup (a) kecakapan pengembangan akademik kecakapan akademik ), dan (b) kecakapan fungsional yang terkait dengan pekerjaan tertentu. ${ }^{21}$

\footnotetext{
18 Anwar, Pendidikan Kecakapan Hidup (Bandung: AlfaBeta, 2012), hlm. 20-21.

19 Jamal Ma'mur Asmani, Sekolah Lifeskills Lulus Siap Kerja ( Jogjakarta: Diva Press, 2009 ), hlm. 30.

20 Ali Nurdin, "Pendidikan Life Skill Dalam Menumbuhkan Kewirausahaan Pada Peserta Didik Pendidikan Nonformal Paket C “, Tarbawi, Volume.02, Nomor.02, (Juli-Desember 2016 ), hlm. 112.

21 Anwar, Pendidikan Kecakapan., hlm. 30.
} 


\section{Strategi Nabi Muhammad SAW dalam entrepreneurship}

Entrepreneurship adalah suatu kemampuan kreatif dan inovatif yang dapat dijadikan suatu sumber daya dan perjuangan untuk menciptakan nilai tambah barang dan jasa yang dilakukan dengan penuh keberanian untuk menghadapi berbagai resiko yang telah ada. Pada dasarnya kemunculan istilah dari entrepreneurship bukanlah suatu hal yang baru. Entrepreneurship sudah pernah dikenal dan dilakukan oleh Nabi Muhammad SAW. Selanjutnya, sejarah pun menyatakan bahwa Nabi Muhammad merupakan sosok entrepreneur yang sukses.

Nabi Muhammad memulai suatu usaha berdagang saat usia 12 tahun. Pada saat itu, Nabi Muhammad melakukan suatu usaha magang dan Nabi Muhammad waktu itu ikut serta magang pada usaha pamannya. Kemudian, suatu saat usaha pamannya mengalami kebangkrutan dan lantas Nabi Muhammad mencari alternatif agar nantinya dapat menemukan solusi dalam kebangkrutan usaha pamannya. Akhirnya Nabi Muhammad memulai menawarkaan suatu jasa menjualkan barang dagangan para saudagar kaya Mekkah. Lambat laun usaha yang dijalankan Nabi Muhammad bisa dibilang sukses, karena beliau dapat menembus negara tetangga dalam berdagangnya. Pada suatu hari, Nabi Muhammad mengajukan penawaran kepada seorang janda kaya yang bernama Siti Khadijah dan dalam hal ini Nabi menerapkan sistem bagi hasil dengan Siti Khadijah. Selanjutnya, dengan bermodalkan kemandirian Nabi Muhammad berhasil mengelola barang dagangan yang diamanahkan Khadijah kepada Nabi Muhammad.

Jadi, modal utama yang dimiliki oleh Nabi Muhammad dalam berdagang yaitu kepercayaan. Dengan kepercayaan tersebut menjadikan Nabi Muhammad menjadi sosok pengusaha yang sukses. Kemudian ketika Nabi Muhammad berdagang sangat memenuhi suatu karakteristik yang terdapat pada entrepreneurship yakni kejujuran, menjaga amanah, percaya diri, spirit, bisnis yang benar-benar bersih, beretiket, berprospek cerah, rajin, tekun, mandiri, pantang menyerah, berani mengambil resiko, dan 
memiliki pribadi yang egaliter. Kesempatan Nabi Muhammad untuk memasuki dunia entrepreneurship dengan cara menjalankan modal orang lain, baik dengan upah maupun dari sistem bagi hasil yang di dapat karena kentalnya nilai-nilai yang terkandung dalam pribadi beliau, dan karena kepiawaiannya dalam skill berdagang serta sifatnya yang dimiliki beliau egaliter sehingga mudah masuk di semua golongan. Hingga akhirnya Nabi Muhammad menjadi sosok yang mendapat julukan pedagang yang Al-Amin.

\section{Implementasi entrepreneurship oleh peserta didik di SDNU Insan Cendekia.}

Peserta didik merupakan orang yang tengah mencari ilmu pengetahuan, keterampilan dan pembentukan karakter tertentu. Peserta didik dipandang sebagai anak yang aktif, bukan anak pasif yang hanya menanti pendidik untuk memenuhi otaknya dengan berbagai informasi. Peserta didik adalah anak yang dinamis, yang secara alami ingin belajar. Di dalam diri peserta didik itu terdapat suatu potensi aktif dan potensi tersebut harus dikembangkan sesuai dengan bakat dan minatnya.

Sesuai dengan kondisi dari peserta didik pada lembaga pendidikan formal yaitu di SDNU INSAN CENDIKIA. Pada lembaga sekolah ini terbilang masih sekolah yang baru karena masih memiliki 4 angkatan saja dan juga sekolah ini merupakan sekolah swasta yang berlabel plus yang terdapat di desa Ngadiluwih Kabupaten Kediri. Terlepas dari itu semua, ternyata sekolah ini dinilai mampu memberikan pembaharuan dengan merayakan milad disekolahnya. Jika dibandingkan dengan sekolah lain yang terdapat di desa Ngadiluwih, sekolah ini memiliki suatu rentetatan acara-acara sewaktu diadakannya milad sekolah.

Sebelum dilakukannya acara milad, terlebih dahulu para pendidik dikumpulkan dan diajak untuk melaksanakan rapat oleh kepala sekolah yaitu Ibu Siti Zulaikhah. Pada saat dilangsungkannya rapat, untuk menyusun acara dalam milad tersebut terdapat pendidik yaitu Ibu Shinta dan Bapak Sandi yang mengusulkan 
untuk diadakannya bazar antara orangtua dan peserta didik. Sebenarnya, pada acara milad di sekolah ini banyak sekali seperti lomba antara peserta didik, periksa dokter bagi orangtua peserta didik, dll. Akan tetapi serangkaian acara yang diselenggarakan pada sekolah ini yang memiliki kaitan dengan entrepreneurship adalah bazar. Bazar di sekolah ini dilaksanakan pada hari Sabtu 18 Maret 2017 dan acara bazar ini masih dilaksanakan pertama kali di sekolah ini. Seperti halnya bazar-bazar yang biasanya, yang terdiri dari beberapa penjual dengan berbagai sajian makanan, minuman, mainan, dll.

Pada acara bazar ini, sekolah melibatkan orangtua untuk berpartisipasi aktif dan kemudian orangtua dibantu oleh anakanaknya. Akan tetapi, tidak menutup kemungkinan jika peserta didik juga di ajak untuk berdagang sendiri dengan teman-temannya. Ternyata sebelum diadakan bazar tersebut, para pendidik memiliki inisiatif yang sangat jitu untuk peserta didiknya. Pendidik memotivasi peserta didik agar memiliki kemauan membantu menjualkan barang dagangan orangtuanya maupun barang dagangan sendiri. Motivasi yang telah diberikan oleh para pendidik tersebut yaitu berupa kisah-kisah Nabi Muhammad yang kala itu menjadi seorang pedagang yang sukses dan para peserta didik juga dijelaskan mengenai ayat Al-Qur'an dan Hadist tentang berdagang agar nantinya para peserta didik dapat melakukan berdagang sesuai yang telah diharapkan oleh pendidik maupun orangtua.

Selanjutnya, para pendidik tersebut juga membuatkan kupon yang nantinya kupon itu dapat dijualkan kepada orang lain dan kupon tersebut dapat ditukarkan dengan beberapa makanan maupun minuman yang tersedia pada penjual bazar tersebut. Adapun peserta didik yang melakukan berdagang sendiri dengan teman-temannya dan mereka berdagang seperti slime, gantungan kunci, makanan ringan, dll. Ternyata jika ditelusuri yang dilakukan oleh peserta didik tersebut, telah menerapkan suatu bidang entrepreneurship. Apabila peserta didik sejak duduk dibangku sekolah dasar sudah dipahamkan yang berkaitan dengan entrepreneurship, 
maka anak-anak tersebut akan menjadi anak yang hebat pada masa depannya nanti karena mereka telah disuguhkan dengan beberapa karakteristik dari entrepreneurship yang sudah mereka jalankan saat ini.

Pada dasarnya kegiatan entrepreneurship ini sangat berkaitan dengan life skills. Life skills atau kecakapan hidup merupakan suatu kemampuan komunikasi secara efektif, kemampuan mengembangkan kerja sama, memiliki kesiapan serta kecakapan untuk bekerja, dan memiliki karakter dan etika untuk terjun ke dunia kerja. Akan tetapi, jika masih pada usia sekolah dasar life skills yang terdapat dalam dirinya meliputi kecakapan hidup umum yang merupakan kecakapan-kecakapan hidup yang dibutuhkan seseorang untuk dapat hidup dan berada di tengahtengah masyarakat. Kecakapan hidup umum (general life skills) yang dapat dibagi menjadi 2 yakni: kecakapan personal dan kecakapan hidup sosial. Life skills yang terdapat pada peserta didik tersebut meliputi kecakapan personal yang telah dilakukan peserta didik yaitu berkaitan tentang apa yang harus mereka jual, bagaimana dengan harganya, bagaimana dengan bahannya, dll. Akan tetapi jika kecakapan hidup sosialnya peserta didik tersebut dapat melakukan tentang bagaimana cara berkomunikasi dengan pembeli, bagaimana dapat menghargai antar penjual yang lain, bagaimana dapat kerjasama antar teman untuk berjualan suatu produk, dll. Oleh karena itu, Apabila peserta didik tersebut menerapkan suatu kegiatan entrepreneurship maka akan berpengaruh terhadap life skills yang terdapat dalam dirinya. Sehingga jika entrepreneurship ini diterapkan secara berturut-turut, maka life skills peserta didik tersebut akan meningkat sekaligus terpenuhi 4 konsep life skills semuanya.

\section{Tantangan dan Peluang Peserta Didik Dalam Menerapkan Entrepreneurship.}

Pada kegiatan entrepreneurship yang dilakukan oleh peserta didik di SDNU INSAN CENDEKIA. Maka peserta didik tersebut 
memiliki kelebihan, diantaranya dapat melatih ketrampilan jual beli, dapat mempererat hubungan silaturrahmi antara pendidik, peserta didik dan orangtua, dapat memperoleh laba, dapat membangkitkan semangat kerjasama antar peserta didik, dan dapat membangun rasa kebersamaan antar semua warga sekolah. Dibalik kelebihan tersebut, pastinya terdapat kekurangan dan kekurangan yang dimunculkan dalam hal ini yaitu kurangnya waktu dalam berjualan, kurangnya tempat yang strategis, masih belum memahami tentang metode berjualan yang tepat, belum adanya pemerataan penggunaan kupon, peserta didik kelas bawah seperti kelas 1 belum mampu melaksanakan berdagang sendiri dan mereka masih menggantungkan orangtua, tidak diberikan ketentuan dalam berjualan alhasil banyak orangtua yang berjualan produk yang sama, dan acara ini tidak dibuka untuk umum.

\section{Simpulan}

Nabi Muhammad memiliki startegi yang jitu dalam melakukan suatu kegiatan entrepreneurship yaitu dengan kejujuran, menjaga amanah, percaya diri, spirit, bisnis yang benar-benar bersih, beretiket, berprospek cerah, rajin, tekun, mandiri, pantang menyerah, berani mengambil resiko, dan memiliki pribadi yang egaliter.

Pada SDNU Insan Cendekia menerapkan suatu kegiatan entrepreneurship. Kegiatan tersebut dilakukan atas partisipasi antara orangtua dan peserta didik, dalam hal ini ada juga peserta didik yang membantu jualan orangtuanya akan tetapi ada juga peserta didik yang berjualan sendiri dengan teman-temannya. Entrepreneurship yang dilakukan oleh peserta didik tersebut tidak lepas dari pendidik yang senantiasa memberikan motivasi entrepreneurship. Ternyata jika peserta didik tersebut menerapkan entrepreneurship, maka akan meningkatkan lifeskills yang terdapat dalam dirinya. Lifeskills tersebut meliputi kecakapan personal dan kecakapan hidup sosial yang lebih lanjut bisa dikembangkan pada kegiatan entrepreneurship. 
Kegiatan entrepreneurship tersebut memiliki beberapa kelebihan diantaranya dapat melatih ketrampilan jual beli, dapat mempererat hubungan silaturrahmi antara pendidik, peserta didik dan orangtua, dapat memperoleh laba, dapat membangkitkan semangat kerjasama antar peserta didik, dan dapat membangun rasa kebersamaan antar semua warga sekolah. Akan tetapi, jika kekurangan dalam melaksanakan entrepreneurship tersebut antara lain kurangnya waktu dalam berjualan, kurangnya tempat yang strategis, metode berjualan yang tidak tepat, belum adanya pemerataan penggunaan kupon, peserta didik kelas bawah belum mampu melaksanakan berdagang sendiri, tidak diberikan ketentuan dalam berjualan, dan acara tersebut tidak dibuka untuk umum. 


\section{DAFTAR PUSTAKA}

Ananto, Purnomo, Pendidikan Kecakapan Hidup Untuk Pencegahan HIV dan AIDS Bagi Guru SMA dan yang Sederajat. Jakarta: Departemen Pendidikan Nasional Pusat Pengembangan Kualitas Jasmani, 2007.

Anwar, Pendidikan Kecakapan Hidup. Bandung: AlfaBeta, 2012.

Aprijon, "Kewirausahaan dan Pandangan Islam". Menara, Vol.12, No. 01. 2013.

Asmani, Jamal Ma'mur, Sekolah Lifeskills Lulus Siap Kerja. Jogjakarta: Diva Press, 2009.

Bakhri, Boy Syamsul, "Masyarakat Ekonomi Asean (Mea) dan Tinjauan dari Perspektif Ekonomi Syariah“. Jurnal Ekonomi. Vol. 25, No. 2. Desember 2015.

Hamdu, Ghullam, "Pengaruh Motivasi Belajar Siswa Terhadap Pestasi Belajar IPA di Sekolah Dasar“. Jurnal Penelitian Pendidikan. Vol. 12, No. 1. April 2011.

Hanika, Silviani, "Pengaruh Pendidikan dan Pelatihan Dan Motivasi Terhadap Kinerja Karyawan Bagian Mekanik“. Jom Fekon. Vol. 1, No.2. April 2014.

Iftikhah, Rizka, "Pengaruh Perhatian Orang Tua Terhadap Motivasi Belajar Siswa“. Jurnal Ilmiah Pendidikan Bimbingan dan Konseling. Jurnal online. Diakses pada tanggal 16 November 2016.

Nurdin, Ali, "Pendidikan Life Skill Dalam Menumbuhkan Kewirausahaan Pada Peserta Didik Pendidikan Nonformal Paket C “. Tarbawi. Vol. 02, No. 02. Juli-Desember 2016.

Prawira, Purwa Atmaja, Psikologi Pendidikan dalam Perspektif Baru. Yogyakarta: Ar-Ruzz Media, 2014. 
Reni, "Pengaruh Kepemimpinan Terhadap Motivasi Kerja Karyawan pada UD. Surya Phone di Samarinda“. EJournal Ilmu Administrasi Bisnis. Vol. 03, No. 04 : ISSN 23555408. 2015.

Siswanto, Agus. The Power Of Islamic Entrepreneurship. Jakarta: Amzah, 2016.

Sitepu, Novi Indriyani, "Prilaku Bisnis Muhammad SAW Sebagai Entrepreneur Dalam Filsafat Ekonomi Islam“. Human Falah. Vol. 3. No. 1. Januari-Juni 2016.

Sutopo, H.B, Metodologi Penelitian Kualitatif. Surakarta: UNS Press, 2002.

Suwarno, Wiji, Dasar-dasar Ilmu Pendidikan. Sleman: Ar-ruzz Media Group, 2009.

Uno, Hamzah B, Teori Motivasi dan Pengukurannya: Analisis di Bidang Pendidikan. Jakarta: Bumi Aksara, 2007.

Wiyani, Novan Ardy, Teacherpreneurship. Jogjakarta: Ar-Ruzz Media, 2012. 